[Regular Paper]

\title{
Deep Desulfurization of Diesel Fuel and Its Color Degradation
}

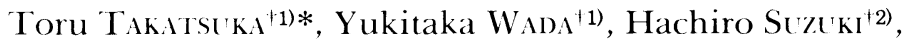 \\ Sho-ei Komatsi ${ }^{\dagger 2}$, and Yasuo Morimura ${ }^{\dagger 2}$ \\ 11) R\&D Center, Chiyoda Corporation, 3-13 Moriya-cho, Kanagawa-ku, Yokohama 221 \\ †2) Yokohama Office, Chiyoda Corporation, 2-12-1 Tsurumichuo, Tsurumi-ku, Yokohama 230
}

(Received April 1 1, 1991)

\begin{abstract}
A matter of the utmost concern about deep desulfurization of diesel fuel in the Japanese market is color degradation. From deep hydrodesulfurization tests of various feedstocks, including model sulfur compounds, it was suspected that the color bodies were derived from newly formed structure of polyaromatics from desulfurized aromatic compounds. And, it is also indicated that higher hydrogen pressure suppresses color degradation of diesel fuel to a great extent, during deep desulfurization.

Additionally, comments were made on the current reaction model of hydrodesulfurization of diesel fuel.
\end{abstract}

\section{Introduction}

Severe regulations against environmental pollution were enforced in the early 1970's in Japan, in advance of the rest of the world. These prompted the development of several environmental protection technologies in Japan, such as those for unleaded gasoline and for desulfurization of fuel oil and flue gas. Recently, the Japanese Central Council for Control of Environmental Pollution proposed a schedule of phased reduction of $\mathrm{NO}_{x}$ and particulates in diesel emissions, whereby the sulfur content of diesel fuel would be reduced to $0.2 \mathrm{wt} \%$ in 1993 and $0.05 \mathrm{wt} \%$ in several years and later to attain the previously established targets of emission control. The first milestone, to reach a $0.2 \mathrm{wt} \%$ sulfur content level in diesel fuel, is not difficult, neither in technological nor economical aspects. But, to attain the final goal of $0.05 \mathrm{wt} \%$ of sulfur, there are several problems to be solved very carefully for the future diesel oil HDS unit.

When most Japanese refiners started feasibility studies on this new investment in deep desulfurization of diesel fuel, the discussion was concentrated on the technology to control the color deterioration of product oil. So far, the Japanese market is highly sensitive to the specification of diesel oil color. It is regarded as the most reliable visual index of quality by the end-user.

The technology was reviewed and comments were made on deep desulfurization of diesel fuel with properties satisfactory to the Japanese market.

\footnotetext{
* To whom correspondence should be addressed.
}

\section{Experiments}

All experiments on hydrodesulfurization of diesel fuel were carried out with fixed bed microreactors, where $30 \mathrm{cc}$ of $\mathrm{KF}-707$ (Ketjen Fine) was loaded with fine $\alpha$-alumina to have a uniform liquid flow in the reactor (For details see reference ${ }^{1)}$ ). For sample analyses appropriate ASTM procedures were employed.

\section{Color Specification of Diesel Fuel}

\section{1 Color Specification in the Current Diesel Fuel Market}

A very right specification on color is demanded for diesel fuel in the Japanese market. Although no standard specification is widely established, every oil company has its own standard of quality control. Table 1 shows three types of representative methods of measuring diesel oil color. These methods are rather different from one another, because they display different terms of quality. ASTM color presents hue of a sample, while Saybolt and APHA presents color on scales of lightness. They roughly correlate to one another in the realm of deep desulfurization, as shown in Fig. 1.

When diesel fuel is desulfurized, the yellow color of straight-run diesel disappears at first, as shown in Fig. 2. It becomes totally clear or transparent at a certain level of conversion, around $80 \%$. But then it becomes colored again, with yellow-green fluorescence, when the conversion is increased beyond about $95 \%$.

Figure 3 illustrates the colors of representative diesel fuel samples purchased in the Yokohama area. They are above ASTM color L. 0.5, though 
Table 1 Typical Methods of Color Analysis

\begin{tabular}{lllc}
\hline & \multicolumn{1}{c}{ Standard } & \multicolumn{1}{c}{ Contents } & Sign \\
\hline ASTM Color & ASTM D1500 & Hue of sample & $0-8$ \\
Saybolt Color & ASTM D156 & Lightness (clear) of sanple & $+30--16$ \\
APHA Color & APHA $^{\text {a) }}$ & Lightness (clear) of sample & $0-500$ \\
\hline
\end{tabular}

a) APHA: American Public Health Association.

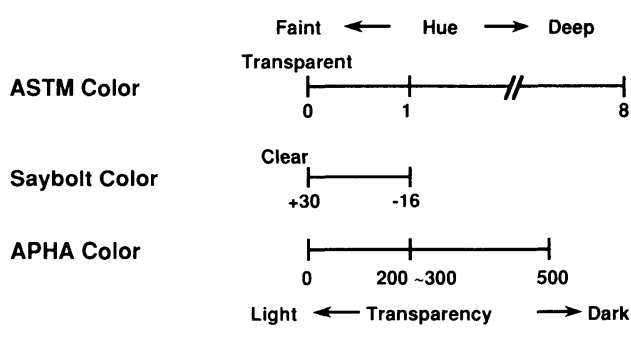

Fig. I Conceptual Color Scales

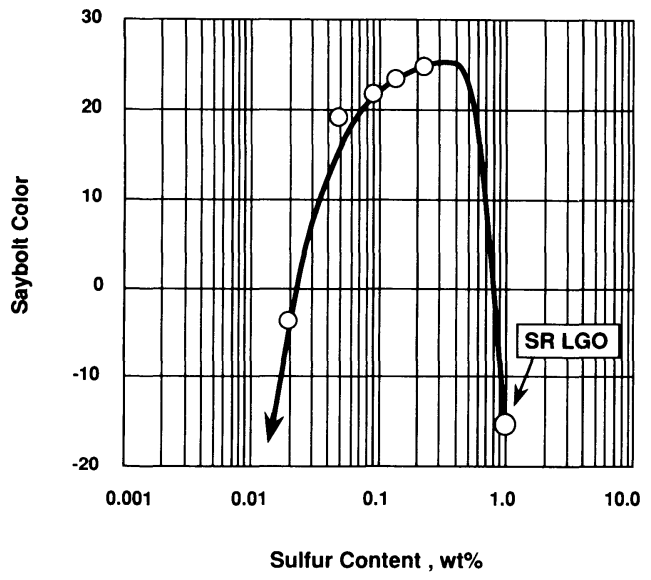

Fig. 2 Change of Color Owing to Deep Desulfurization of SR LGO

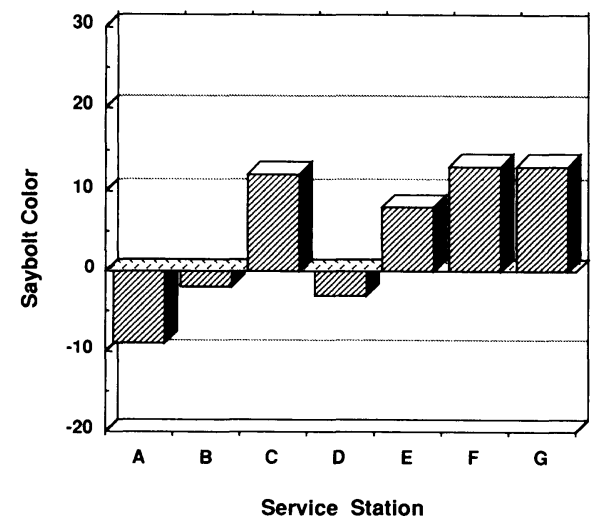

Fig. 3 Color Distribution in the Diesel Fuel Market

some differences are observed. The same level of color would be required in the future market for diesel fuel, too.

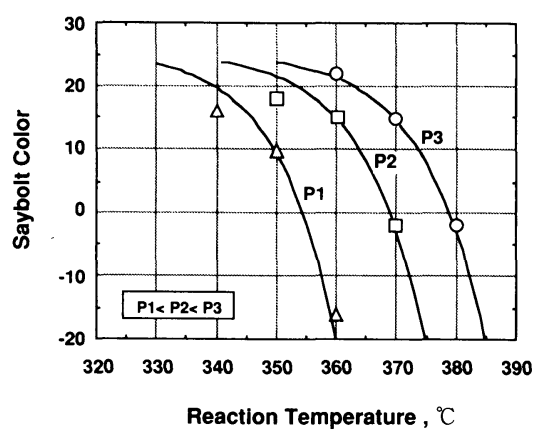

Fig. 4 Effect of Operating Conditions on Changes in Color

\section{2 Color Degradation and Operating Condi- tions}

The color of diesel fuel is affected by the reaction condition of hydrodesulfurization, but its sensitivities to reaction temperature, residence time and hydrogen partial pressure are rather different from those in the desulfurization of diesel fuel. This is quite an important consideration in the design of a deep desulfurization unit.

In the operation of a hydrodesulfurization unit reactor, the temperature is increased to compensate the aging loss of catalyst activity. The color of diesel fuel degrades in accordance with temperature, increasing from the very start of run (SOR), and this continues rapidly after reaching a certain level of temperature. On the other hand, higher partial pressure of hydrogen can suppress the degradation of color to a great extent as shown in Fig. 4. This indicates that an appropriate pressure should be set in the design of the process to provide sufficient allowance of rise in temperature $\Delta T\left(T_{\mathrm{SOR}}-T_{\mathrm{EOR}}\right)$ to attain the required operating term.

For a standard design of deep desulfurization, partial pressure of hydrogen of 50 to $60 \mathrm{~kg} / \mathrm{cm}^{2} \mathrm{G}$ is required to attain a 1 - to 2 -year run on-stream. The data collected in the laboratory are normally the results of isothermal reaction. In a commercial unit, however, temperature gradient is 10 to $15^{\circ} \mathrm{C}$ from the top of a reactor to the bottom. Sometimes, even a hot spot is observed in the reactor bed. The predicted upper-limit temperature against color degradation, obtained from experimental results, should be regarded as the maximum permissible temperature in the reactor, 
or a rate model of color degradation is necessary for proper design of deep desulfurization unit for diesel fuel.

\section{Mechanism of Color Degradation}

\section{1 Variation of Color Bodies}

The color of a substance originates in a selective absorption of lightwaves in the visible range and is derived from the change of energy state of $\pi$ electron in aromatic compounds. Recently, the relationship between color and molecular structure has been studied from chemical aspects ${ }^{2}$. Substance is colored by an extremely small amount of color body, comparable to the way that odors are generated. That makes it very difficult to detect an unknown color body in diesel fuel, which is a complex mixture.

Generally, a color is detected when there exist color bodies such as molecules with structures $=\mathrm{C}=\mathrm{C}=-\mathrm{C}=\mathrm{NH}$, or $>\mathrm{C}=\mathrm{S}$ bonded to aromatics. But it is not simple to attribute those molecules to the color bodies of deeply desulfurized diesel fuel, because those structures are removed during the deep desulfurization of diesel fuel. It is a process of color disappearance as shown in Fig. 2.

Then, how does diesel fuel regain color again? In the desulfurization mechanism, sulfur is removed first onto the catalyst, and then the activated molecular site is quenched by hydrogen. If the site is not easily quenched by causes such as steric hindrance, it is left as an active radical and a condensed aromatic structure could be formed. That will be the reason why a higher hydrogen pressure is effective to control color degradation of diesel fuel as confirmed in Fig. 4. The color bodies are suspected to be derived from this new structure of polyaromatics from desulfurized aromatic compounds.

From this idea, the range of sulfur removal from non-thiophenic and mono benzothiophenic compounds is defined as a process of color disappearance. Color degradation of diesel fuel starts again from the range of desulfurization of dibenzothiophenic compounds to the heavier, which are considered tough compounds to be hydrogenated by $\mathrm{Co}-\mathrm{Mo}$ or Ni-Co-Mo catalyst.

\section{2 Fractionations of Colored Diesel Fuel}

The range of boiling points of color bodies was investigated by fractionating deep desulfurized colored diesel fuel. The sample was desulfurized under hydrogen pressure of $50 \mathrm{~kg} / \mathrm{cm}^{2} \mathrm{G}$, which is higher than the conventional desulfurization condition of diesel fuel, and the sulfur content was $0.013 \mathrm{wt} \%$. It was fractionated into eight samples, as shown in Fig. 5.

In Fig. 6 are illustrated the observed Saybolt

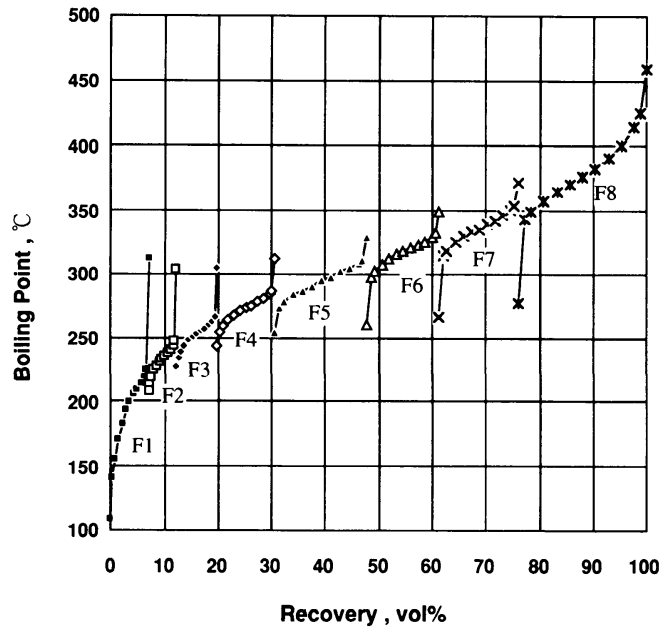

Fig. 5 Fractionations of Colored Diesel Fuel

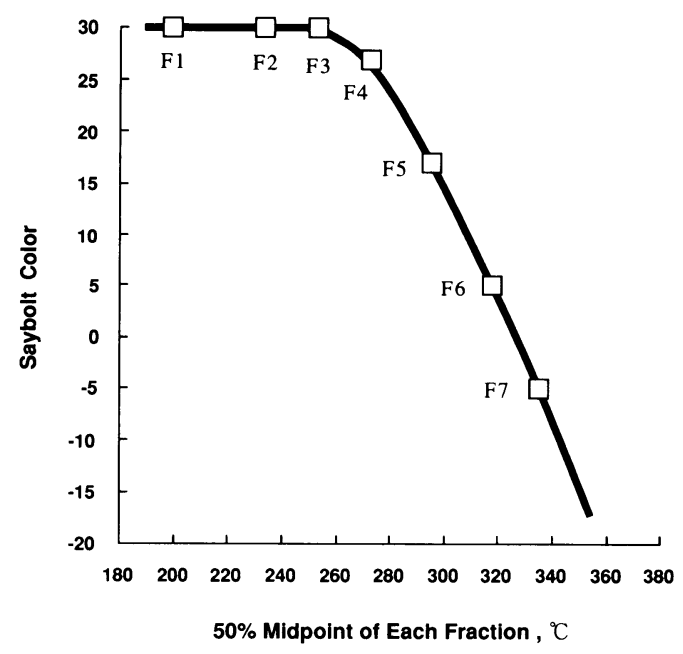

Fig. 6 Saybolt Color of Each Fraction

Color of each sample against its boiling point, where the datum of sample with highest-boiling point, sample $\mathrm{F} 8$ (above $340^{\circ} \mathrm{C}$ ), is not shown because it was below the scale of color analysis $(<-16$ of Saybolt Color). This indicates that the color bodies produced in deep desulfurization did not exist in the samples below boiling point of $250^{\circ} \mathrm{C}$, but that they existed widely in the samples above boiling point of $250^{\circ} \mathrm{C}$. The color bodies were rich in the range of higher boiling points.

The results imply that the mechanism of production of color bodies, which was discussed in the previous section, is formation of new molecules. The data also show color of diesel fuel treated by deep desulfurization can be upgraded by adjusting its end-point, if it can be done.

\section{3 Color Degradation of Diesel Fuel of Various Origins}

Variously derived diesel fuels were deeply desulfurized to verify their coloring process. Table 2 
Table 2 Properties of Various Feedstocks

\begin{tabular}{|c|c|c|c|c|}
\hline & $\begin{array}{c}\text { A } \\
\text { SR I.GO }\end{array}$ & $\stackrel{\text { B }}{\mathrm{LCGO}}$ & $\begin{array}{c}\mathrm{C} \\
\mathrm{LCO}\end{array}$ & $\begin{array}{c}\text { D } \\
\text { Mixed GO }\end{array}$ \\
\hline$\left[\mathrm{dl} 5 / 4^{\circ} \mathrm{C}\right]$ & 0.852 & 0.784 & 0.913 & 0.877 \\
\hline Sulfur $\quad[w t \%]$ & 0.99 & 1.27 & 0.18 & 1.03 \\
\hline Saybolt Color & -15 & $<-16$ & $<-16$ & $>+30$ \\
\hline Saturates $\quad\left[\mathrm{vol}^{\%}\right]$ & 65 & 44 & 17 & - \\
\hline Olefins & 0 & 28 & 0 & - \\
\hline Aromatics [vol\%] & 35 & 28 & 83 & _- \\
\hline \multicolumn{5}{|l|}{ Distillation (D2887) } \\
\hline $10 \%$ & 268 & 79 & 190 & 414 \\
\hline $50 \%$ & 302 & 196 & 249 & 488 \\
\hline $90 \%$ & 345 & 286 & 338 & 540 \\
\hline
\end{tabular}

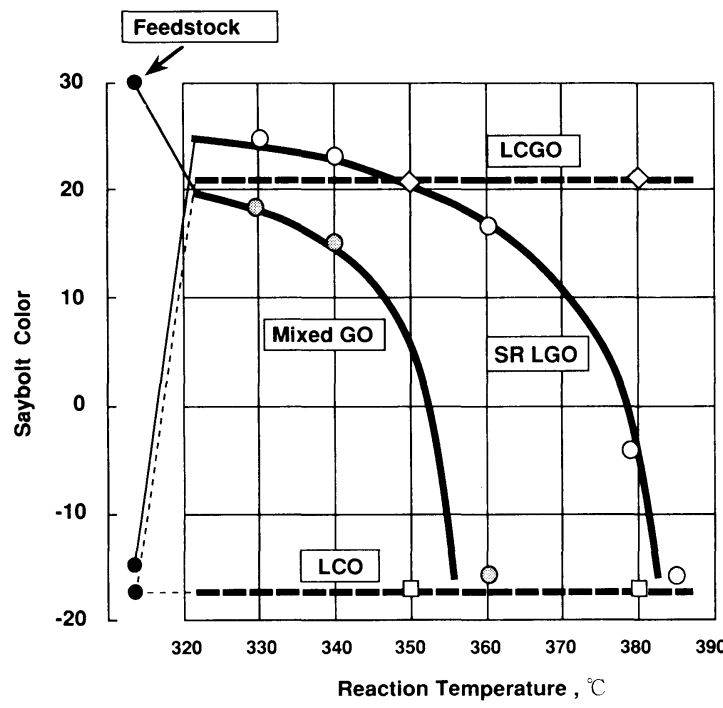

Fig. 7 Change of Color on Feedstock of Varying Origins

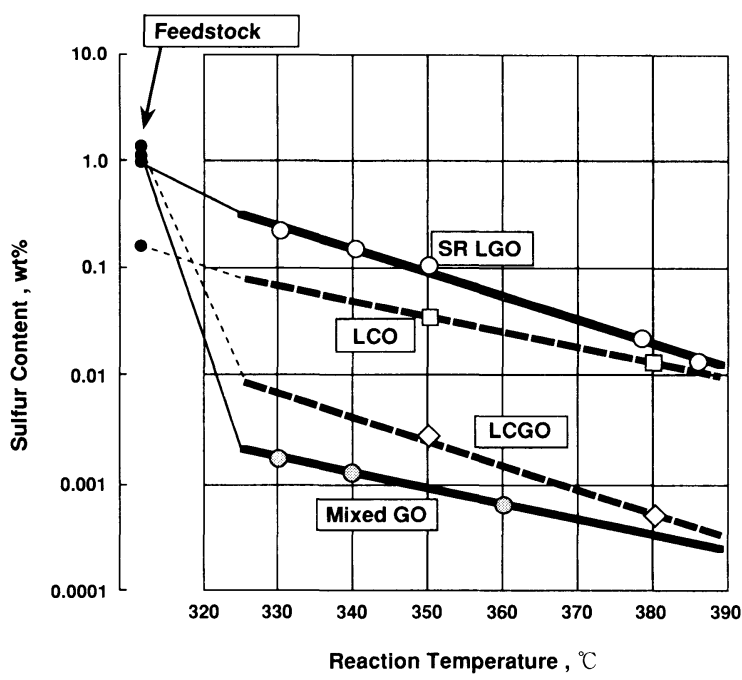

Fig. 8 Reactivity of Desulfurization on Feedstock of Varying Origins

summarizes their origins and representative properties. A, B and C are straight-run, thermally cracked, and catalytically cracked diesel fuels, respectively. D is fluid paraffin mixed with thio- phene, benzothiophene and dibenzothiophene, previously dissolved into a small amount of $\alpha$ methylnaphthalene to provide $c a$. $1 \mathrm{wt} \%$ sulfur content. Those four kinds of feedstocks were deeply desulfurized under a typical design pressure of $50 \mathrm{~kg} / \mathrm{cm}^{2} \mathrm{G}$. The process of their color degradation and desulfurization are shown in Fig. 7 and Fig. 8, respectively.

Feedstock A, a straight-run diesel fuel, which originally had Saybolt Color -15, lost its color to Saybolt Color +25 reading, initially, at a desulfurization level of $c a .90 \%$. But it is suddenly degradated, by color bodies having yellow-green florescence, to a final level of Saybolt Color -16, in the range of deep desulfurization.

Feedstock B, derived from thermal cracking of residual oil, was highly contaminated by sulfur and color bodies. Its sulfur was easily removed, however, without any color degradation because of its lower boiling point, as shown in Fig. 7 and Fig. 8. It was kerosene, rather than a diesel fraction.

On the other hand, feedstock $\mathrm{C}$, derived from catalytic cracking, was highly resistant to hydrotreating, as has been pointed out. The rate of desulfurization was small and no color improvement was observed, in the specified condition.

Feedstock D, which was specially prepared in the present test, as mentioned before, showed very interesting qualities. Transparent sample D became colored like a straight-run diesel fuel in the desulfurization range causing removal of dibenzothiophene. The result shows clearly that the production of color bodies did not occur with heterogeneous molecules found in straight-run diesel fuel, but occurred with newly formed molecules.

The results obtained with feedstock $\mathrm{B}$ can be correlated to removal of sulfur from nonthiophenic and mono benzothiophenic compound as discussed in 4. 1. It is a process of color disappearance. Desulfurized molecules were easily hydrogenated and further polymerization was inhibited in the process.

On the contrary, a color degradation was observed in the desulfurization of transparent feedstock D. Desulfurized dibenzothiophene was suspected to be a precursor of color bodies, because it has a structure which difficult to be hydrogenated. It could be polymerized and showed color of polyaromatics in the process.

It is suggested that the color degradation model proposed in 4.1 is verified to a certain extent by the experiments.

\section{Comments on Desulfurization Rate}

For the conventional HDS reactor, the reaction 


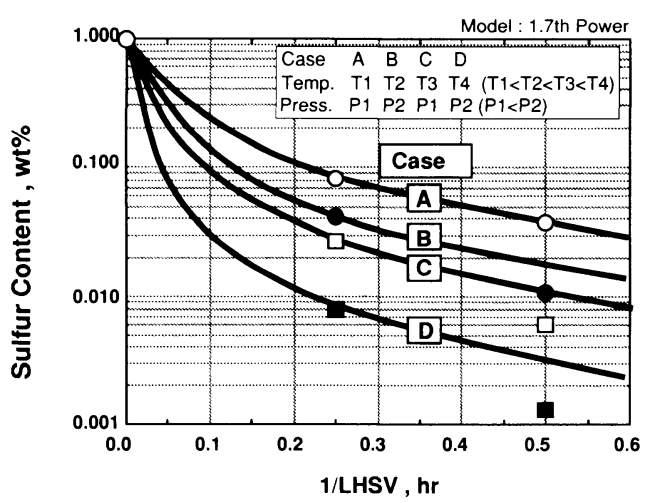

Fig. 9 Fitting with Current Model to 1.7th Power

rate is represented to the 1.7 th power reaction against total sulfur content in diesel fuel ${ }^{13)}$.

$$
-\frac{\mathrm{d} c}{\mathrm{~d} t}=k c^{1.7}
$$

,where

$c$ : total sulfur content,

$k$ : rate constant of hydrodesulfurization for total sulfur,

$t$ : residence time.

Actually, many reactions are taking place simultaneously for various types of sulfur compounds in the desulfurization of diesel fuel ${ }^{4)}$. The rate expression to the 1.7th power of total sulfur is just a simplified model for a limited range of desulfurization. The model has not yet been confirmed as applicable to the range of deep desulfurization. Experiments A, B, C and D were carried out to confirm the HDS model for reactor design in a sufficiently wide range under $0.05 \mathrm{wt} \%$ of sulfur in the realm of deep desulfurization by changing the operating conditions.

As shown in Fig. 9, the current model to the 1.7th power expression follows the test results approximately down to the level of $0.04 \mathrm{wt} \%$ of sulfur as observed in experiment $\mathrm{A}$, but it cannot represent the data in the range of sulfur below $0.04 \mathrm{wt} \%$, as shown in experiments B, C and D. The results indicate that the model should be used within the cited limit.

For the design of deep HDS of diesel fuel, the two-component model is recommended as follows.

$$
-\frac{\mathrm{d}\left(c_{1}+c_{2}\right)}{\mathrm{d} t}=k_{1} c_{1}+k_{2} c_{2}
$$

,where

$c_{1}, c_{2}$ : contents of pseudosulfur components,

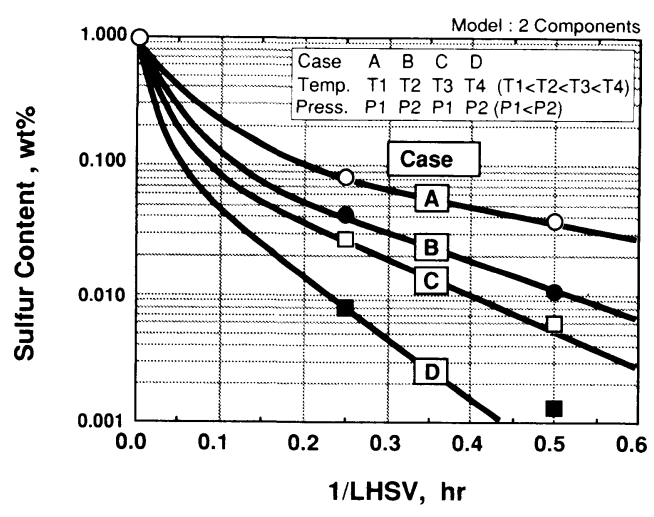

Fig. 10 Fitting with Two-component Model

$k_{1}, k_{2}$ : rate constants of hydrodesulfurization for pseudosulfur components.

It has two pseudocomponents in the model, representing the reactions of non-thiophenic sulfur compounds and thiophenic compounds, respectively. Results of simulation with the twocomponent model are shown in Fig. 10. The predicted results represent experiments conducted down to the level of $0.006 \mathrm{wt} \%$ of sulfur, as observed in experiment $\mathrm{C}$.

The target of $0.05 \mathrm{wt} \%$ of sulfur for deep desulfurization of diesel fuel is just on the border line, where both models can be applied to practical use. This indicates that conventional design practices of reactor design, intended to meet current requirements, should be verified by experimentation prior to begin new investment in deep HDS unit for diesel fuel.

\section{Conclusions}

1) Higher hydrogen pressure suppresses color degradation of diesel fuel during deep desulfurization.

2) The mechanism of color degradation was discussed, and the color bodies were suspected to be derived from newly formed structure of polyaromatics from desulfurized aromatic compounds. 3 ) The current reaction model to the 1.7 th order expression was verified by tests conducted in the realm of deep desulfurization of diesel fuel.

\section{References}

1) Akimoto, O., Iwamoto, Y., Kodama, S., Takeuchi, C., Prep., Div., Petrol. Chem., ACS, Washington D. C., August 28, 1983.

2) The Society of Synthetic Chemistry, "Color Chemical Dictionary”, CMC INC., Japan (1988).

3) Fushiyama, A., PETROTECH, 1, (7), 705 (1978).

4) Japan Petroleum Institute, "Sekiyu Seisei Purosesu", Saiwai Shobo, Tokyo (1984), p. 119.

石油学:会編, “石油精製プロセス”, 幸書房, 東京 (1984), p. 119. 
要旨

\title{
軽油の深度脱硫と色相変化
}

\author{
高塚 透 $^{\dagger 1)}$, 和田幸隆 ${ }^{\dagger 1)}$, 鈴木八郎 ${ }^{\dagger 2)}$, 小松昭英 ${ }^{\dagger 2)}$, 森村恭郎 ${ }^{\dagger 2)}$ \\ †1) 千代田化工建設(株)総合研究開発センター, 221 横浜市神奈川区守屋町 3-13 \\ †2) 千代田化工建設(株)横浜本店, 230 横浜市鶴見区鶴見中央 2-12-1
}

中央公害対策審議会の答申に基づいて, 日本の石油各社は軽 油の硫黄含有量を $0.05 \%$ にまで低隇すべく検討を行ってい る。日本市場では軽油の色相(Table 1, Fig. 1)のスペックが諸 外国に比べて厳しく(Fig. 3), 軽油の深度脱硫ではその色相の 変化(Fig. 2)が最大の関心事となっている。

深度脱硫軽油の色相は運転圧力により大きく改善されること が分かったが(Fig. 4)，さらにその着色機構を検討するために タイプの異なる 4 種の原料油( Table 2)について実験を行った
(Figs. 7, 8)。また，着色成分が $250{ }^{\circ} \mathrm{C}$ 以上の高沸点留分に偏 在する(Figs. 5, 6)ことを確認した。以上の結果から, 詳しい 検討の余地が残されているものの, 着色は 2 環以上のチオフ エン類の脱硫に伴う多環芳香族の生成によるものと推定した。 また，軽油の脱硫反応モデルとされている 1.7 次反応式の深 度脱硫領域での適用性について検討するとともに(Fig. 9)，よ り適用範囲の広い 2 成分系反応モデルを提案した $($ Fig. 10)。

\section{Keywords}

Hydrodesulfurization, Diesel fuel, Color degradation, Reactor 